\title{
Corrosion Behavior of API 5L X80 Steel in the Produced Water of Onshore Oil Recovery Facilities
}

\author{
Edkarlla Sousa Dantas de Oliveira ${ }^{a}$, Roseana Florentino da Costa Pereira ${ }^{a}$, Ivanilda Ramos de \\ Melo $^{b}$, Maria Alice Gomes de Andrade Lima ${ }^{b}$, Severino Lepoldino Urtiga Filho \\ ${ }^{a}$ Departamento de Engenharia Mecânica, Universidade Federal de Pernambuco, Avenida Professor \\ Moraes Rego 1235, Cidade Universitária, 50670-901 Recife, PE, Brazil \\ ${ }^{b}$ Departamento de Engenharia Química, Universidade Federal de Pernambuco, Av. Prof. Arthur Sá s/n, \\ Cidade Universitária, 50740-521 Recife, PE, Brazil
}

Received: December 09, 2016; Revised: May 29, 2017; Accepted: September 15, 2017

\begin{abstract}
High-strength low-alloy steel is used in pipelines, which transport oil/gas and also produced water in the process of the secondary recovery of oil. This paper investigates the corrosion of X80 steel after immersion in static systems (biotic and abiotic). The corrosion rate, the corrosion morphology and the hardness of the coupons were investigated. The corrosion products were determined by SEM/EDS and $\mathrm{XRD}$. The corrosion rates of the coupons in the biotic system were moderate and had an agressive pit morphology, while those of the coupons in the abiotic system were low with less aggressive pit. The hardness of the coupons after exposure to the systems of produced water was not changed compared with that of the control coupons. The corrosion products formed in the biotic system were $\mathrm{Fe}(\mathrm{OH})_{3}$, $\mathrm{Fe}(\mathrm{OH})_{2}, \mathrm{FeOOH}, \mathrm{Fe}_{3} \mathrm{O}_{4}, \mathrm{FeS}_{2}, \mathrm{FeCl}_{3}$, and in the abiotic system, $\mathrm{NaCl}, \mathrm{CaCl}_{2}$ and $\mathrm{SrSO}_{4} . \mathrm{BaSO}_{4}$ and $\mathrm{CaCO}_{3}$ were identified in both systems.
\end{abstract}

Keywords: API $5 L X 80$, biocorrosion, produced water, SEM/EDS, XRD.

\section{Introduction}

The development of high strength steel pipelines is of great economic importance to the oil industry. The technology of these pipelines has allowed for greater transmission of oil and gas due to increased internal pressure while decreasing the wall thickness of the pipe ${ }^{1}$. API 5L X80 steel has excellent mechanical properties such as high strength, good toughness, good fatigue resistance and excellent corrosion resistance ${ }^{2-4}$. During the process of secondary oil recovery a large amount of produced water is generated which contains dissolved salts, inorganic and organic constituents, solids, oil, dissolved gases $\left(\mathrm{CO}_{2} \mathrm{e}\right.$ $\mathrm{H}_{2} \mathrm{~S}$ ) and microorganisms ${ }^{5,6}$. The activity of microorganisms can change the nature of the aqueous environment which leads to hydrocarbon being degraded, clogging, souring and microbiologically-induced corrosion (MIC), and more specifically the localized corrosion of pipeline steel ${ }^{7-9}$. Sulfate reducing bacteria (SRB) are the bacteria most investigated in causing $\mathrm{MIC}$ in the oil industry ${ }^{10-12}$. However there are other groups of bacteria that are prejudicial to pipelines such as iron-reducing and oxidizing bacteria, $\mathrm{CO}_{2}$ reducing bacteria and manganese oxidizing bacteria ${ }^{1,7}$. In the literature there are very few reports about the corrosion behavior of API 5L X80 steel in produced water with mixed cultures under static conditions. The exposure conditions are of great importance for characterizing corrosion products formed on

*e-mail: edkarllaquimica@hotmail.com. the surface of steel. The corrosion process, in some cases, causes the formation of corrosion products that increase the hardness on the steel's surface ${ }^{13}$. Recent studies in the oil and gas industry show the influence of microorganisms that cause corrosion ${ }^{8,14-16}$. This paper sets out to investigate the corrosion of high-strength, low-alloy (API 5L X80) steel in produced water systems with and without microorganisms for 60 days. The material was characterized by its chemical composition and metallographic analyses. In this study, the microbiological composition of produced water was quantitatively characterized. The corrosion rate and the morphology of the corroded surface were determined by the weight loss technique and scanning electron microscopic images, respectively. The hardness of the coupons after immersion in the systems was investigated using the Vickers hardness test. The corrosion products were characterized by scanning electron microscopy coupled with energy dispersive spectroscopy (SEM/EDS) and X-ray diffraction (XRD).

\section{Experimental Procedures}

\subsection{Material}

The coupons were cut from API 5L X80 pipeline steel, which had a chemical composition (wt.\%) of $0.08 \mathrm{C}, 0.3 \mathrm{Si}$, $1.82 \mathrm{Mn}, 0.009 \mathrm{P}, 0.001 \mathrm{~S}, 0.17 \mathrm{Cr}, 0.01 \mathrm{Ni}, 0.20 \mathrm{Mo}, 0.01$ $\mathrm{Cu}, 0.037 \mathrm{Al}, 0.024 \mathrm{~V}, 0.003 \mathrm{~W}, 0.021 \mathrm{Ti}, 0.081 \mathrm{Nb}$ and balance Fe. The size of the coupons used was $30 \times 10 \times 5$ 
$\mathrm{mm}$. The surface of the coupons was abraded with sandpapers (220-1200 mesh) and polished with diamond paste (3 and 1 $\mu \mathrm{m})$. After polishing, the coupons were cleaned in acetone and alcohol, and air dried. The characterization of the microstructure of coupons was obtained after etching them with $2 \%$ nital reagent for 10 seconds, followed by analysis in an inverted Axio Observer-Z1 Zeiss optical microscope. Figure 1 shows there was a polygonal ferrite microstructure with iron carbides at the grain boundaries.

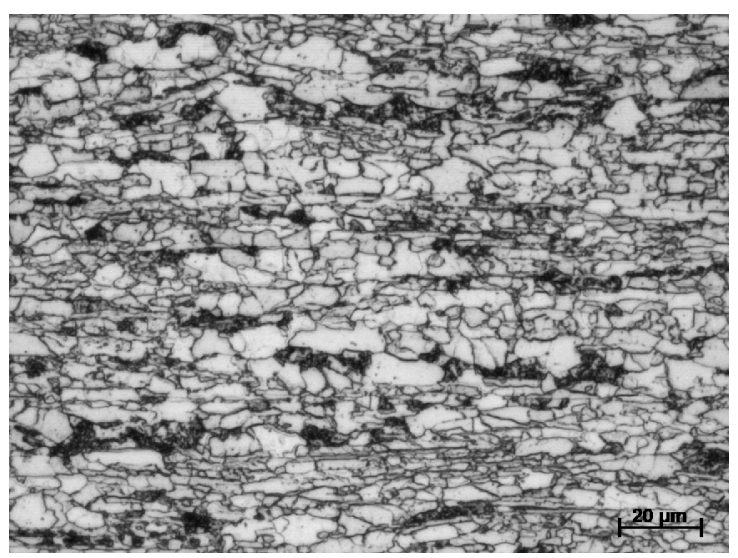

Figure 1. Microstructure of API 5L X80 steel (magnification 500x).

\subsection{Water sample}

Oilfield produced water was collected from a Brazilian oil production plant. The biotic system consisted of oilfieldproduced water samples which were microbiologically characterized. The Most Probable Number (MPN) method was used to quantify the following groups of planktonic microorganisms: total anaerobic, acid-producing aerobic and anaerobic, and sulfate-reducing bacteria (SRB) ${ }^{17}$. Total aerobic and precipitating iron bacteria were quantified by the Colony Forming Unit (CFU) method ${ }^{18}$. The abiotic system (without microorganisms) consisted of the produced water samples from the oilfeld which were filtered through membranes with $0.22 \mu \mathrm{m}$ pores. After filtration, $1 \mathrm{mg} / \mathrm{L}$ sodium hypochlorite was added daily to remove microbial contaminants. Both static immersion systems were evaluated for 60 days at room temperature.

\subsection{Cultivation of microorganisms}

The group of planktonic microorganisms was quantified by inoculating $1 \mathrm{~mL}$ of the produced water in the reducing solutions, followed by reinoculation in different culture medium. The composition in $(\mathrm{g} / \mathrm{L})$ of the total anaerobic bacteria culture medium, which was prepared under nitrogen purges, was as follows: $30.0 \mathrm{NaCl}$ and 30.0 thioglycolate ( $\mathrm{pH}$ 7.0). The composition in $(\mathrm{g} / \mathrm{L})$ of the acid-producing aerobic and anaerobic bacteria culture medium was: 30.0 $\mathrm{NaCl}, 10.0$ sucrose, 10.0 tryptone, 1.0 beef extract and
0.018 phenol red ( $\mathrm{pH}$ 7.2). The culture medium used for acid-producing anaerobic bacteria was purged with nitrogen. The composition in $(\mathrm{g} / \mathrm{L})$ of the SRB culture medium prepared under nitrogen purges was as follows: $30.0 \mathrm{NaCl}$, $0.5 \mathrm{KH}_{2} \mathrm{PO}_{4}, 1.0 \mathrm{NH}_{4} \mathrm{Cl}, 1.0 \mathrm{Na}_{2} \mathrm{SO}_{4}, 0.67 \mathrm{CaCl}_{2} .2 \mathrm{H}_{2} \mathrm{O}$, $1.68 \mathrm{MgCl}_{2} \cdot 6 \mathrm{H}_{2} \mathrm{O}, 7.0 \mathrm{~mL}$ sodium lactate $(50 \%), 1.0$ yeast extract, 0.1 ascorbic acid, 1.9 agar-agar, $4.0 \mathrm{~mL}$ resazurin $(0.025 \%)$ and $0.5 \mathrm{FeSO}_{4} .7 \mathrm{H}_{2} \mathrm{O}(\mathrm{pH} 7.6)^{19}$. The composition in $(\mathrm{g} / \mathrm{L})$ of the total aerobic bacteria culture medium was: $30.0 \mathrm{NaCl}$ and 22.5 plate count agar (PCA) medium $(\mathrm{pH}$ 7.0). The composition in $(\mathrm{g} / \mathrm{L})$ of the precipitating iron bacteria culture medium was: $30.0 \mathrm{NaCl}, 0.5\left(\mathrm{NH}_{4}\right)_{2} \mathrm{SO}_{4}$, $0.2 \mathrm{CaCl}_{2} .2 \mathrm{H}_{2} \mathrm{O}, 0.5 \mathrm{MgSO}_{4} .7 \mathrm{H}_{2} \mathrm{O}, 0.5 \mathrm{NaNO}_{3}, 10.0$ ferric ammonium citrate and $0.5 \mathrm{~K}_{2} \mathrm{HPO}_{4}(\mathrm{pH} 7.0)^{20}$. The reducing solution contained the following constituents in $(\mathrm{g} / \mathrm{L}): 30.0$ $\mathrm{NaCl}, 0.124$ sodium thioglycolate, 0.1 ascorbic acid and 4.0 $\mathrm{mL}$ resazurin $(0.025 \%)(\mathrm{pH} 7.6)$. All components were per liter of distilled water. All groups of microorganisms were incubated at $35^{\circ} \mathrm{C}$. All culture media and solutions were sterilized in autoclave at $1 \mathrm{~atm}$ and $121^{\circ} \mathrm{C}$ for 20 minutes.

\subsection{Weight loss, corrosion rate and analysis of the morphology of corrosion}

The experiments were conducted on open glass static test cell. The coupons were suspended by nylon threads and totally immersed in the produced water. Coupons were weighed before being placed within the biotic and abiotic systems. The coupons were removed from the systems after 15, 30, 45 and 60 days, and the biofilms and corrosion products were removed from the surface of coupons with a non-metallic rod. The coupons were immersed in Clark solution, followed by ultrasonic cleaning in distilled water. Afterwards they were cleaned in isopropyl alcohol and acetone, dried and weighed. Subsequently, the corrosion rate was evaluated using the ASTM G1-03 standard ${ }^{21}$. The corrosion rate of the coupons was determined as shown below: Corrosion rate $(\mathrm{mm} / \mathrm{y}):\left(\frac{K \times W}{A \times T \times D}\right)$. Where $\mathrm{K}=\mathrm{a}$ constant $=8.76 \times 10^{4}, \mathrm{~W}=$ weight loss $(\mathrm{g}), \mathrm{A}=$ area $\left(\mathrm{cm}^{2}\right)$, $\mathrm{T}=$ time of exposure $(\mathrm{h})$ and $\mathrm{D}=$ density of carbon steel $\left(7.86 \mathrm{~g} / \mathrm{cm}^{3}\right)$. The NACE RP 0775 Standard was used to evaluate the corrosivity of the coupons ${ }^{22}$. After establishing the corrosion rate, the corrosion morphology on the coupons was investigated using a scanning eletron microscope (SEM) TM 3000 Hitachi.

\subsection{Hardness test}

The Vickers hardness (VH) test was carried out on the coupons before (control) and after immersion in the biotic and abiotic systems. The mean value of 6 readings of the indentation length was taken along the direction of the thickness. The $10 \mathrm{~kg}$ load applied was maintained for $15 \mathrm{~s}$ for each reading. Hardness tests were conducted on a 
durometer DuraScan 70 EMCO TEST using a pyramidal diamond indenter, as per the ASTM E384-11 Standard ${ }^{23}$.

\subsection{Characterization of corrosion products}

After the immersion test, the coupons were removed from the systems, and dried in a dessicator. Subsequently, the surface of the coupon was analyzed. The elements and chemical compounds of corrosion products on the coupon were analyzed by SEM coupled with energy dispersive spectroscopy (EDS) and X-ray diffraction (XRD), respectively. SEM analysis was carried out using a TM 3000 Hitachi microscope operating at $15 \mathrm{kV}$. EDS analysis was semiquantitative. XRD analysis was carried out using a 7000 Maxima Shimadzu X-ray diffractometer operating with a Cu source $(\lambda=0.154060 \AA)$, at the voltage of $40 \mathrm{kV}$, current of $30 \mathrm{~mA}$ and scan speed of $1 \% \mathrm{~min}$.

\section{Results and Discussion}

\subsection{Quantification of planktonic microorganisms}

Table 1 presents the cell concentration of planktonic microorganisms in the produced water sample. The total aerobic bacteria were in higher concentrations in the produced water sample. Aerobic bacteria consume dissolved oxygen in the fluid which provides the anaerobic environment with the propitious growth of anaerobic bacteria ${ }^{15,24}$. SRB, total anaerobic, acid-producing aerobic and anaerobic bacteria were also present in the produced water. SRB are the main causes of microbiologically-induced corrosion in the operating systems of the oil industry ${ }^{12,25}$. Iron-precipitating bacteria were not detected in the produced water, probably due to the low cell concentration or because the counting method was limited.

\subsection{Corrosion test analysis}

The corrosion rate for weight loss of API 5L X80 steel coupons after 15, 30, 45 and 60 days of immersion into biotic and abiotic systems is shown in Figure 2.

A significant difference between the corrosion rates was observed. The biotic system showed a higher corrosion rate, between 0.029 and $0.057 \mathrm{~mm} /$ year, with moderate corrosivity. In the abiotic system, the corrosion rate varied between 0.002 and $0.010 \mathrm{~mm} /$ year, this being considered low corrosivity. The addition of sodium hypochlorite biocide did not increase the corrosion rate of the coupons exposed to the abiotic system. It is likely that metabolic products of

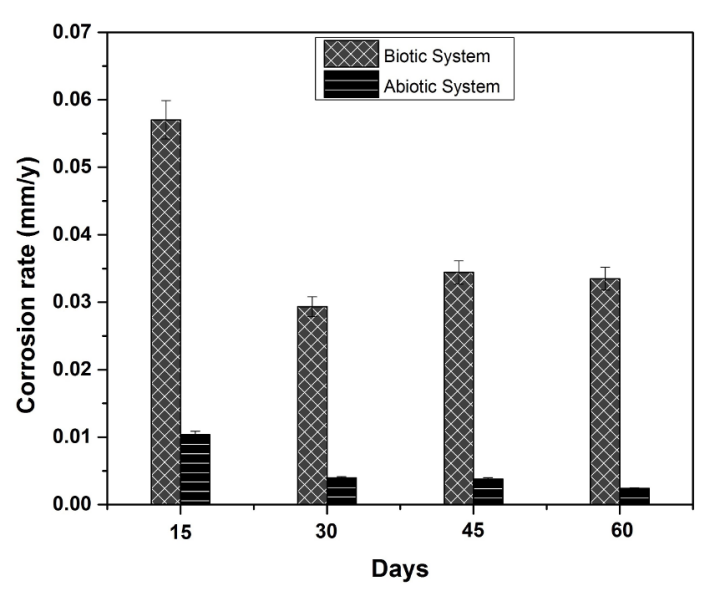

Figure 2. Corrosion rate by weight loss of API 5L X80 steel coupons.

microorganisms and production of exopolymeric substances (EPS) contributed to the increase in the corrosion rate, and thus promoted biodegradation of the coupons in the biotic system $^{26}$. These microbial metabolites can be organic acids, hydrogen sulfide or other sulfur species ${ }^{12}$. The deterioration of metal surfaces because of bacteria occurs due to the initial formation and subsequent adhesion of biofilms, which as a result of physical and chemical reactions modify this interface ${ }^{27}$. Major changes in this interface are observed after biofilm forms, such as changes in $\mathrm{pH}$, the redox potential, the types of ions in electrochemical corrosion and even the variables used to evaluate the corrosion rate ${ }^{28}$. Cetin and $\mathrm{Aksu}^{29}$ analyzed after 30 days the corrosion rates by weight loss of the low alloy steel in culture medium with and without Desulfotomaculum sp. The researchers observed that the corrosion rate of the biotic system $(0.000012 \mathrm{~mm} / \mathrm{year})$ was four times higher than the abiotic system $(0.000002 \mathrm{~mm} /$ year). AlAbbas et al. ${ }^{1}$ observed higher values of corrosion rates of API 5L X80 steel in the biotic system (values above $1.5234 \mathrm{~mm} /$ year) after 200 hours, while the abiotic system presented a rate of $0.25391 \mathrm{~mm} /$ year throughout the test. Mishra $^{7}$ evaluated the corrosion rates of API 5L X80 steel in produced water with iron reducing bacteria. The ironreducing bacteria consortium inhibited the corrosion of the steel in the biotic system, reflected by low values of corrosion rate $(0.3022 \mathrm{~mm} /$ year $)$. In the abiotic system, the corrosion rates were higher with a maximum value of $5.0782 \mathrm{~mm} /$ year after 200 hours of testing. Oliveira et al. ${ }^{30}$ investigated the corrosion rate by weight loss of carbon steel SAE 1010 after 28 days of immersion in seawater with and without sodium hypochlorite. The results showed high corrosion

Table 1. Planktonic microorganisms in produced water.

\begin{tabular}{cccccc}
\hline $\begin{array}{c}\text { Group of } \\
\text { microorganisms }\end{array}$ & Total aerobic & Total anaerobic & $\begin{array}{c}\text { Acid-producing } \\
\text { aerobic }\end{array}$ & $\begin{array}{c}\text { Acid-producing } \\
\text { anaerobic }\end{array}$ & $\begin{array}{c}\text { Iron- } \\
\text { precipitating } \\
\text { bacteria }\end{array}$ \\
\hline $\begin{array}{c}\text { Cell } \\
\text { concentration }\end{array}$ & $\begin{array}{c}1.2 \times 10^{4} \\
\mathrm{CFU} / \mathrm{mL}\end{array}$ & $\begin{array}{c}1.1 \times 10^{3} \\
\mathrm{MPN} / \mathrm{mL}\end{array}$ & $\begin{array}{c}7.0 \times 10 \\
\mathrm{MPN} / \mathrm{mL}\end{array}$ & $\begin{array}{c}2.5 \times 10^{2} \\
\mathrm{MPN} / \mathrm{mL}\end{array}$ & $\mathrm{Undetected}$ \\
\hline
\end{tabular}


rate in the seawater system (control), while in the seawater with sodium hypochlorite system there was a reduction of the corrosion rate and the existing microorganisms. Figure 3 displays the SEM images of the coupons after cleaning and removing corrosion products.

Micrographs of the coupons immersed in both biotic and abiotic systems (Figure 3) exhibited localized corrosion, probably by pitting. However, the images of the steel immersed in the biotic system (Figure 3 (a-d)) showed more severe localized corrosion (indicated by white arrows) as compared to the abiotic system (Figure 3 (e-h)). After biofilm has formed on the metal surface because of the microbial consortia, the biofilm produces high concentrations of sulfide and other compounds that potentially prompt an increase in the corrosion process. Sulfate-reducing bacteria have an influence on the corrosion of ferrous alloys, and generally promote pitting corrosion. This is a more severe type of corrosion than uniform corrosion due to its rapid penetration into the structure of the material and may cause failures ${ }^{1,27}$. The morphologies shown in Figure 3 correspond to corrosion rates, by weight loss of the system as shown in Figure 4. Wu et al. ${ }^{31}$ analyzed an X80 steel surface using SEM, after removing the films formed on systems containing SRB under yield stress. Small pittings were found in the micrographs of the system with SRB, when compared to those of the sterile system, both without load. Perpendicular micro-cracks were identified in the micrographs of SRB and sterile systems, both with load. In the SRB system, the number, density, width and length of the cracks were higher than in the sterile system, thus highlighting the synergistic effect between bacteria and yield stress.

\subsection{Measurement of hardness}

Hardness tests were performed on API 5L X80 steel coupons before immersion and after $8,10,15,30$ and 60 days of immersion in biotic and abiotic systems, and the test results are presented in Figure 4. Figure 5 shows the microstructure of the steel after the immersion test.

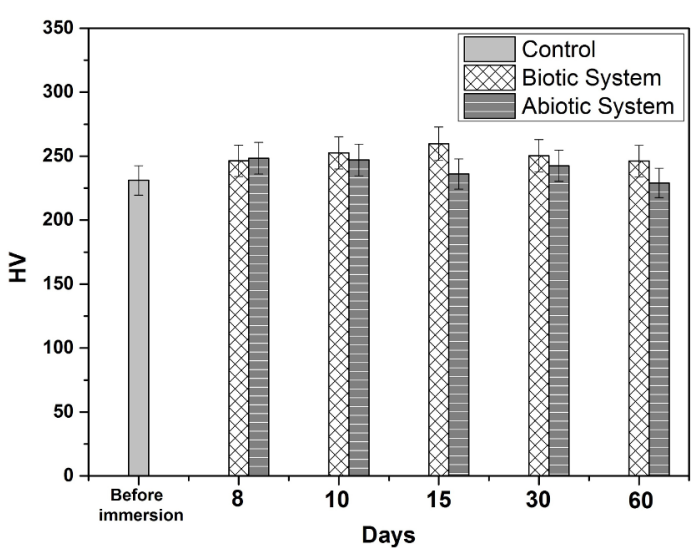

Figure 4. Hardness measurement of the API 5L X80 steel coupons.

Similar micrographs were observed in the other periods investigated. No significant difference in hardness values was found in the systems studied. The consortium of microorganisms and their aggressive metabolites did not cause changes in the microstructure (Figure 5), and consequently did not change the hardness of the API 5L X80 steel coupons (Figure 4), although an increase was observed in corrosion rates and localized corrosion on the surface of steel after immersion tests with microorganisms. Studies show that changes in the microstructure and hardness of API 5L X80 steel usually occur after heat treatment or welding processes $^{32,33}$. According to Walsh et al. ${ }^{34}$ the weld regions have microstructural heterogeneities that are attractive to micro-organisms, which are responsible for causing the microbiologically-induced corrosion.

\subsection{Analysis of corrosion products}

Figure 6 shows the SEM-EDS analysis of the corrosion products formed on the surface of API $5 \mathrm{~L}$ X80 steel coupons after 60 days. The areas analyzed in the SEM images by EDS were marked with black circles.

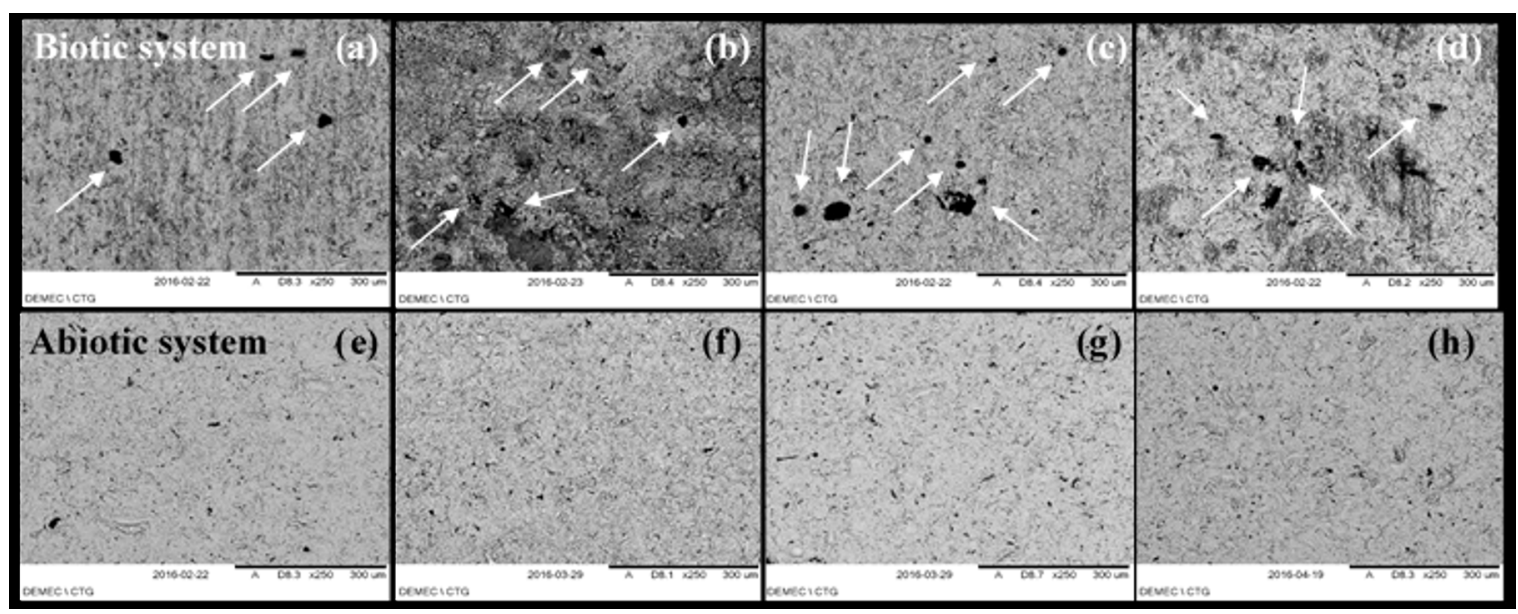

Figure 3. SEM analysis of cleaned coupon surface after: (a, e) 15, (b, f) 30, (c, g) 45 and (d, h) 60 days of exposure in biotic and abiotic systems. 


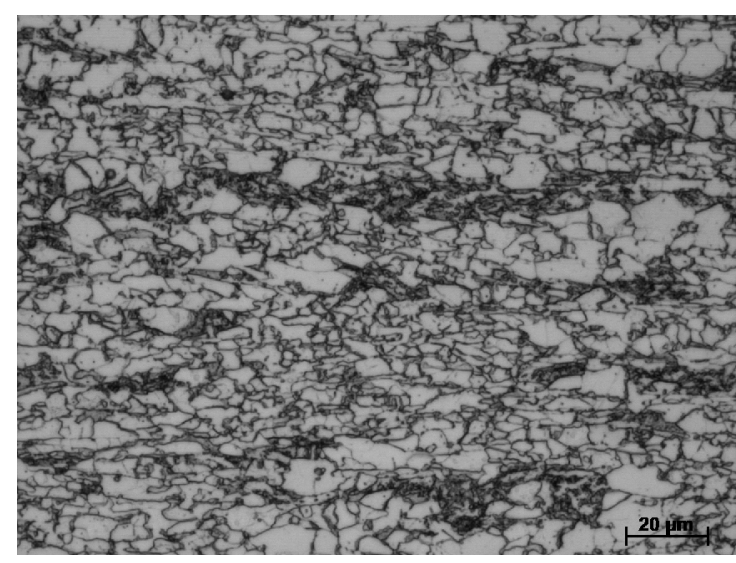

Figure 5. Microstructure of the API 5L X80 steel coupons after 10 days of immersion in the biotic system (magnification 500x).

The micrographs in Figure 6 ( $a$ and $b$ ) show corrosion products which are dense and porous with different morphologies on the coupon surface after immersion in the biotic system. The EDS analysis in Figure 6 (a1 and b1) suggests that the main corrosion products consist of the elements: $\mathrm{C}, \mathrm{O}, \mathrm{Fe}$, $\mathrm{S}, \mathrm{Ba}, \mathrm{Si}, \mathrm{Cl}$ and $\mathrm{Ca}$. The micrographs in Figure 6 (c and d) show salt crystals deposit on the surface of coupons after immersion in the abiotic system. The EDS analysis in Figure 6 (c1 and $\mathrm{d} 1$ ) suggests that the main corrosion products consist of the elements: $\mathrm{O}, \mathrm{Cl}, \mathrm{Na}, \mathrm{Ca}, \mathrm{Mg}$ and $\mathrm{Si}$. The produced water typically has a high concentration of dissolved salts that account for the increase of corrosion in pipes. Chloride anion $\left(\mathrm{Cl}^{-}\right)$is the salt that is in the greatest quantity. However, sulfate $\left(\mathrm{SO}_{4}{ }^{2-}\right)$, carbonate $\left(\mathrm{CO}_{3}{ }^{2-}\right)$ and bicarbonate $\left(\mathrm{HCO}_{3}{ }^{-}\right)$are found in small quantities in this produced water. The cations most commonly found are sodium $\left(\mathrm{Na}^{+}\right)$and potassium $\left(\mathrm{K}^{+}\right)$, calcium $\left(\mathrm{Ca}^{2+}\right)$ and magnesium $\left(\mathrm{Mg}^{2+}\right)^{35-37}$. Figure 7 presents the analysis by X-ray diffraction of the corrosion products formed on the surface of API 5L X80 steel coupons from the biotic and abiotic systems.

The crystalline phases identified in peaks belonging to the corrosion products which had formed on the coupon immersed in the biotic system were the following (Figure 7 (a)): cubic ferric hydroxide $\left(\mathrm{Fe}(\mathrm{OH})_{3}\right)$, hexagonal ferrous hydroxide $\left(\mathrm{Fe}\left(\mathrm{OH}_{2}\right)\right)$, orthorhombic $\mathrm{FeOOH}$, cubic facecentered ( $\mathrm{CFC})\left(\mathrm{Fe}_{3} \mathrm{O}_{4}\right)$ magnetite, orthorhombic barium sulfate $\left(\mathrm{BaSO}_{4}\right)$, orthorhombic calcium carbonate $\left(\mathrm{CaCO}_{3}\right)$, cubic pyrite $\left(\mathrm{FeS}_{2}\right)$, and hexagonal ferric chloride $\left(\mathrm{FeCl}_{3}\right)$. In aerobic environments, iron-precipitating bacteria oxidize ferrous ions to ferric ions, and these ferric ions precipitate as ferric hydroxide due to the following reactions ${ }^{15,38}$ :

$$
\begin{aligned}
\mathrm{Fe}^{2+}+1 / 4 \mathrm{O}_{2}+\mathrm{H}^{+} & \rightarrow \mathrm{Fe}^{3+}+1 / 2 \mathrm{H}_{2} \mathrm{O} \\
\mathrm{Fe}^{2+}+1 / 4 \mathrm{O}_{2}+5 / 2 \mathrm{H}_{2} \mathrm{O} & \rightarrow \mathrm{Fe}(\mathrm{OH})_{3}+2 \mathrm{H}^{+}
\end{aligned}
$$

The formation of ferrous hydroxide occurs from the iron oxidation reaction, as shown in Equations 3 and $4^{39}$ :

$$
\begin{aligned}
& \text { Water reduction: } 2 \mathrm{H}_{2} \mathrm{O}+2 \mathrm{e}^{-} \rightarrow \mathrm{H}_{2(\mathrm{~g})}+2 \mathrm{OH}^{-} \\
& \text {Iron oxidation: } \mathrm{Fe}_{(s)}+2 \mathrm{OH}^{-} \rightarrow \mathrm{Fe}(\mathrm{OH})_{2(\mathrm{~s})}+2 \mathrm{e}^{-}
\end{aligned}
$$

According to Liu et al. ${ }^{15}$ ferrous hydroxide can be oxidized to form compounds such as $\mathrm{FeOOH}, \mathrm{Fe}_{2} \mathrm{O}_{3}$ and $\mathrm{Fe}_{3} \mathrm{O}_{4}$. FeOOH is the hydrated form of $\mathrm{Fe}_{2} \mathrm{O}_{3}$ which may have sub-forms: goethite $(\alpha-\mathrm{FeOOH})$, akaganeite $(\beta-\mathrm{FeOOH})$ and lepidocrocite $(\gamma-\mathrm{FeOOH})^{40}$. Magnetite is a ferric oxide derived from the transformation of ferrous hydroxide in the absence of oxygen, as a result of the following reaction ${ }^{39,40}$ :

$$
3 \mathrm{Fe}(\mathrm{OH})_{2(s)} \rightarrow \mathrm{Fe}_{3} \mathrm{O}_{4(s)}+\mathrm{H}_{2(\mathrm{~g})}+2 \mathrm{H}_{2} \mathrm{O}
$$

The barium sulfate and calcium carbonate are precipitated and cause fouling in oil fields because of their low solubility in water. Generally, barium sulfate is formed when the high concentration of sulfate ions in injection water (e.g. seawater) mixes with barium ions from formation water (e.g. from an oil well) as shown in the following reaction ${ }^{41,42}$ :

$$
\mathrm{Ba}^{2+}+\mathrm{SO}_{4}^{2-} \rightarrow \mathrm{BaSO}_{4}
$$

When barium sulfate is associated with sulfate-reducing bacteria, this further enhances the corrosion process in secondary oil recovery systems $\mathrm{s}^{43}$. Calcium carbonate precipitates after increasing the temperature and/or a reduction in pressure as shown in the following reaction ${ }^{41}$ :

$$
\mathrm{Ca}^{2+}+2 \mathrm{HCO}_{3}^{-} \rightarrow \mathrm{CaCO}_{3}+\mathrm{H}_{2} \mathrm{O}+\mathrm{CO}_{2}
$$

Pyrite is the most stable form of iron sulfide, and is derived from biological reactions caused by sulfate-reducing bacteria ${ }^{44}$. This formation of iron sulfide, depending on the case, may increase the corrosion or even protect the meta ${ }^{12}$. Iron chloride can be formed by iron-precipitating bacteria in media with a high chloride concentration ${ }^{44}$. The crystalline phases identified in peaks belonging to the corrosion products formed on the coupon immersed in abiotic system were the following (Figure 5 (b)): orthorhombic barium sulfate, orthorhombic and monoclinic strontium sulfate $\left(\mathrm{SrSO}_{4}\right)$, orthorhombic, rhombohedral and hexagonal calcium carbonate $\left(\mathrm{CaCO}_{3}\right)$, CFC sodium chloride $(\mathrm{NaCl})$, orthorhombic calcium chloride $\left(\mathrm{CaCl}_{2}\right)$ and cubic body-centered (CCC) $\alpha$-Fe. Strontium sulfate, barium sulfate and calcium carbonate are low water solubility salts, which cause fouling in pipes in the oil industry ${ }^{41}$. Produced water contains sodium and calcium chlorides as dissolved salts. According to Neff et al. ${ }^{36}$ the concentration of dissolved salts in produced water 


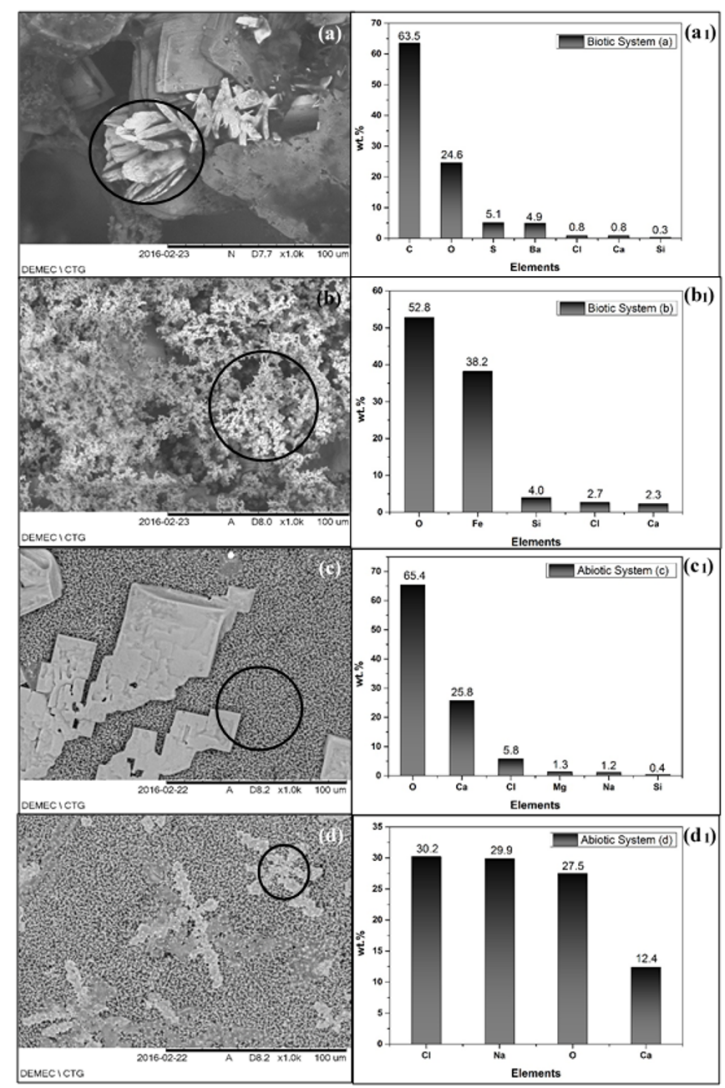

Figure 6. SEM-EDS of the API 5L X80 steel coupons after immersion test: $\left(a, a_{1}, b, b_{1}\right)$ biotic system and $\left(c, c_{1}, d, d_{1}\right)$ abiotic system.

may be greater than in seawater. According to Munirasu et al. ${ }^{45}$ sodium and calcium ions are among the cations most commonly found in produced water. The $\alpha$-Fe identified in the XRD analysis is the naked coupon surface, on which there was no salt deposit. Chemical elements, suggested in the analysis by EDS (Figure 6), were found in the crystalline phases identified in the XRD patterns of biotic and abiotic systems (Figure 7). Liu et al. ${ }^{35}$ used EDS and XRD to identify the chemical elements and corrosion products formed on
Q235 steel pipes in produced water. $\mathrm{FeOOH}$ was identified at the bottom of the pipe, and the compounds $\mathrm{CaCO}_{3}$ and $\mathrm{Mg}_{6} \mathrm{Al}_{2} \mathrm{CO}_{3} .(\mathrm{OH})_{16} \cdot 4 \mathrm{H}_{2} \mathrm{O}$ in the corrosion layers. Xu et al. ${ }^{46}$ used XRD to analyse the corrosion products formed on the surface of low-alloy steel coupons after 365 days. The researchers indicated the presence of $\mathrm{Fe}_{3} \mathrm{O}_{4}$ on both coupon positions in the system (upward and downward surfaces). In addition to $\gamma$-FeOOH on the coupon with an upward surface, $\mathrm{CaCO}_{3}$ and $\alpha-\mathrm{FeOOH}$ were on the coupon with a downward surface. Shi et al. ${ }^{47}$ used XRD, SEM and transmission electron microscopy (TEM) to find the corrosion products formed on API X60 steel coupons in acidic solutions containing $\mathrm{H}_{2} \mathrm{~S}$ and $\mathrm{NaCl} 5 \%$. The researchers varied the temperature $\left(60-150^{\circ} \mathrm{C}\right)$, the pressure of $\mathrm{H}_{2} \mathrm{~S}(0.15$ to $5 \mathrm{MPa})$ and the exposure time $(72-216 \mathrm{~h})$. The corrosion products found were: tetragonal crystal mackinawite, cubic FeS, (intermediate between mackinawite and pyrrhotite) troilite, hexagonal crystal pyrrhotite and cubic pyrite. Yaro et al. ${ }^{13}$ used XRD to evaluate the corrosion products formed on API X65 steel coupons after 3 hours of exposure in produced water and $\mathrm{CO}_{2}$, with and without acetic acid. X-ray diffractogram showed cementite $\left(\mathrm{Fe}_{3} \mathrm{C}\right)$ and siderite $\left(\mathrm{FeCO}_{3}\right)$ in the coupons in contact with acetic acid, and siderite in the coupons without contact with the acetic acid.

\section{Conclusions}

The planktonic microorganisms present in produced water (from the biotic system) increased corrosion in API $5 \mathrm{~L}$ X80 steel. The corrosion rate and pitting corrosion morphology is more severe in the steel coupons of the biotic system (moderate corrosivity) compared with those of the abiotic system (low corrosivity). In the biotic system, the microorganisms released agressive metabolites that increased deterioration of the metal surface. The hardness of steel did not change significantly after exposure to microorganisms due to the test temperature and the formation of corrosion products that did not alter the mechanical properties of the
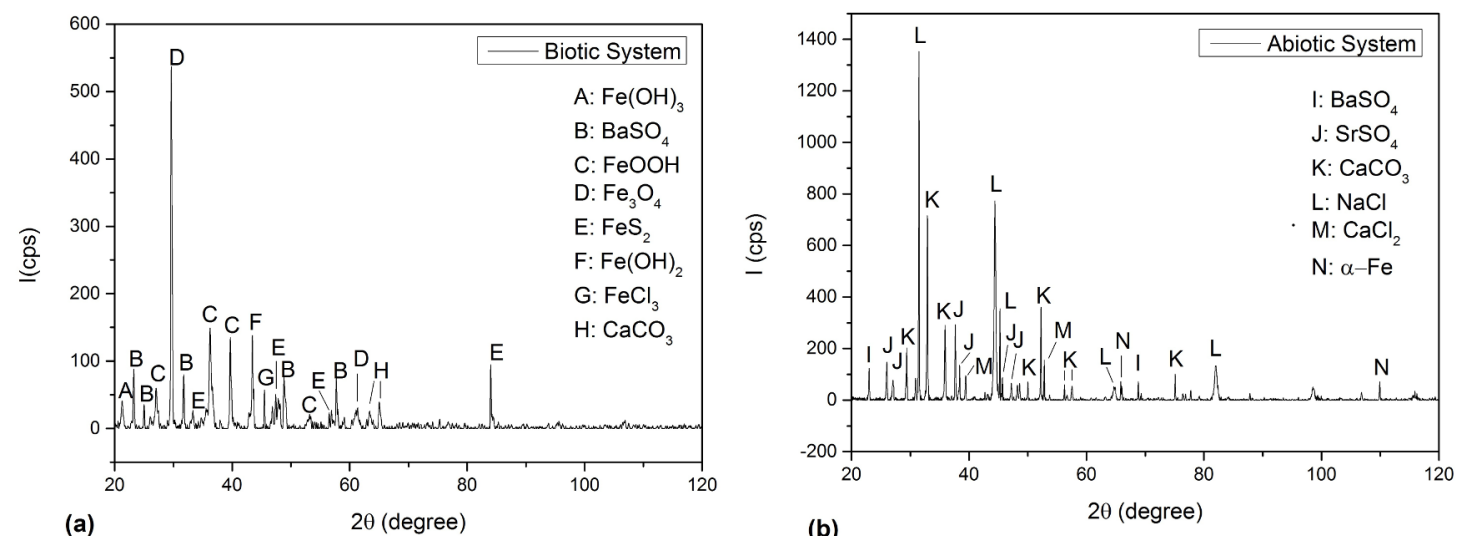

Figure 7. X-ray diffractogram of corrosion products formed on API 5L X80 steel coupons immersed in (a) biotic and (b) abiotic systems. 
steel coupons. XRD revealed the formation of iron oxides and hydroxides, iron sulfide, iron chloride, barium sulfate and calcium carbonate on the steel surface immersed in the biotic system. Chlorides of sodium and calcium, strontium sulfate, barium sulfate, and calcium carbonate were deposited on the steel immersed in the abiotic system. Further studies should be conducted to investigate the behavior of this steel under dynamic flow conditions and temperature variation to test how these affect the use of this steel in the petroleum industry.

\section{Acknowledgements}

The authors would like to acknowledge the support received from CAPES, CNPq and the Programa de Recursos Humanos da Petrobras - PRH-203.

\section{References}

1. AlAbbas FM, Williamson C, Bhola SM, Spear JR, Olson DL, Mishra B, et al. Influence of sulfate reducing bacterial biofilm on corrosion behavior of low-alloy, high-strength steel (API$5 \mathrm{~L}$ X80). International Biodeterioration \& Biodegradation. 2013;78:34-42.

2. Wang Y, Zhao W, Ai H, Zhou X, Zhang T. Effects of strain on the corrosion behaviour of X80 steel. Corrosion Science. 2011;53(9):2761-2766.

3. Zhao W, Xin R, He Z, Wang Y. Contribution of anodic dissolution to the corrosion fatigue crack propagation of X80 steel in 3.5 wt.\% NaCl solution. Corrosion Science. 2012;63:387-392.

4. Aydin H. Relationship between a bainitic structure and the hardness in the weld zone of the friction-stir welded X80 APIgrade pipe-line steel. Materials and Technology. 2014;48(1):1522.

5. Silva D, Gonçalves M, Costa A. Optimization of an Epifluorescence Microscopy Technique for rapid quantification of bacteria associated to corrosion products in produced water. Corrosão e Protecção de Materiais. 2013;32(4):105-107.

6. Araújo L, Carvalho L, Reznik L, Lutterbach M, Sérvulo E. Efeito de biocidas na corrosão induzida microbiologicamente do aço duplex em água de produção de petróleo. Corrosão e Protecção de Materiais. 2013;32(4)108-114.

7. Mishra B. Corrosion Characterization of Advanced Steels for Use in the Oil \& Gas Industry. International Journal of Metallurgical Engineering. 2013;2(2):221-229.

8. Chen X, Wang G, Gao F, Wang Y, He C. Effects of sulfatereducing bacteria on crevice corrosion in X70 pipeline steel under disbonded coatings. Corrosion Science. 2015;101:1-11.

9. Okoro C, Ekun AO, Nwume MI, Lin J. Molecular analysis of microbial community scructures in Nigerian oil production and processing facilities in order to access souring corrosion and methanogenesis. Corrosion Science. 2016;103:242-254.

10. Sarioğlu F, Javaherdashi R, Aksöz N. Corrosion of a drilling pipe steel in an environment containing sulfate-reducing bacteria. International Journal of Pressure Vessels and Piping. 1997;73(2):127-131.

11. Liu $\mathrm{H}, \mathrm{Xu} \mathrm{L}$, Zeng J. Role of corrosion products in biofilms in microbiologically induced corrosion of carbon steel. British Corrosion Journal. 2000;35(2)131-135.

12. Enning D, Garrelfs J. Corrosion of Iron by Sulfate-Reducing Bacteria: New Views of an Old Problem. Applied and Environmental Microbiology. 2014;80(4)1226-1236.

13. Yaro AS, Abdul-Khalik KR, Khadom AA. Effect of $\mathrm{CO}_{2}$ corrosion behavior of mild steel in oilfield produced water. Journal of Loss Prevention in the Process Industries. 2015;38:24-38.

14. AlAbbas FM, Williamson C, Bhola SM, Spear JR, Olson DL, Mishra B, et al. Microbial Corrosion in Linepipe Steel Under the Influence of a Sulfate-Reducing Consortium Isolated from an Oil Field. Journal of Materials Engineering and Performance. 2013;22(11):3517-3529.

15. Liu H, Fu C, Gu T, Zhang G, Lv Y, Wang H, et al. Corrosion behavior of carbon steel in the presence of sulfate reducing bacteria and iron oxidizing bacteria cultured in oilfield produced water. Corrosion Science. 2015;100:484-495.

16. Li XX, Liu JF, Yao F, Wu WL, Yang SZ, Mbadinga SM, et al. Dominance of Desulfotignum in sulfate-reducing community in high sulfate production-water of high temperature and corrosive petroleum reservoirs. International Biodeterioration \& Biodegradation. 2016;114:45-56.

17. Harrigan WF. Laboratory Methods in Food Microbiology. San Diego: Academic Press, 1998.

18. Tortora GJ, Funke BR, Case CL. Microbiologia. Porto Alegre: ArtMed; 2000.

19. Postgate JR. The Sulphate-Reducing Bacteria. Cambridge: Cambridge University Press; 1983.

20. Companhia Ambiental do Estado de São Paulo - CETESB. Norma L5.201 - Contagem de bactérias heterotróficas - Método de ensaio. São Paulo: CETESB; 2006. 14 p.

21. ASTM International. ASTM G1-03 - Standard Practice for Preparing, Cleaning, and Evaluating Corrosion Test Specimens. West Conshohocken: ASTM International; 2011.

22. National Association of Corrosion Engineers - NACE. NACE RP 0775 - Standard Practice for Preparing, Cleaning, and Evaluating Corrosion Test Specimens. Houston: NACE; 2005.

23. ASTM International. ASTM E384-11 - Standard Test Method for Knoop and Vickers Hardness of Materials. West Conshohocken: ASTM International; 2011.

24. Song X, Yang Y, Yu D, Lan G, Wang Z, Mou X. Studies on the impact of fluid flow on the microbial corrosion behavior of product oil pipelines. Journal of Petroleum Science and Engineering. 2016;146:803-812.

25. AlAbbas FM, Spear JR, Kakpovbia A, Balhareth NM, Olson DL, Mishra B. Bacterial attachment to metal substrate and its effects on microbiologically-influenced corrosion in transporting hydrocarbon pipelines. Journal of Pipeline Engineering. 2012;11(1):63-72.

26. Dall'Agnol LT, Cordas CM, Moura JJG. Influence of respiratory substrate in carbon steel corrosion by a Sulphate Reducing 
Prokaryote model organism. Bioelectrochemistry. 2014;97:4351.

27. Javed MA, Stoddart PR, Wade SA. Corrosion of carbon steel by sulphate reducing bacteria: Initial attachment and the role of ferrous ions. Corrosion Science. 2015;93:48-57.

28. Videla HA. Metal Dissolution/Redox in Biofilms. In: Characklis WG, Wilderer PA, eds. Structure and Function of Biofilms. Chichester: Wiley; 1989. p. 301-320.

29. Cetin D, Aksu ML. Corrosion behavior of low-alloy steel in the presence of Desulfotomaculum sp. Corrosion Science. 2009;51(8):1584-1588.

30. Oliveira SH, Lima MAGA, França FP, Vieira MRS, Silva P, Urtiga Filho SL. Control of microbiological corrosion on carbon steel with sodium hypochlorite and biopolymer. International Journal of Biological Macromolecules. 2016;88:27-35.

31. Wu T, Xu J, Sun C, Yan M, Yu C, Ke W. Microbial corrosion of pipeline steel under yield stress in soil environment. Corrosion Science. 2014;88:291-305.

32. Shin SY, Oh K, Lee S, Kim NJ. Correlation study of microstructure, hardness, and Charpy impact properties in heat affected zones of three API X80 linepipe steels containing complex oxides. Metals and Materials International. 2011;17(1):29-40.

33. Niu J, Qi L, Liu Y, Ma L, Feng Y, Zhang J. Tempering microstructure and mechanical properties of pipeline steel X80. Transactions of Nonferrous Metals Society of China. 2009;19(Suppl 3):s573-s578.

34. Walsh D, Pope D, Danford M, Huff T. The effect of microstructure on microbiologically influenced corrosion. JOM. 1993;45(9):2230 .

35. Liu Y, Zhang Y, Yuan J. Influence of produced water with high salinity and corrosion inhibitors on the corrosion of water injection pipe in Tuha oil field. Engineering Failure Analysis. 2014;45:225-233.

36. Neff JM, Lee K, DeBlois EM. Produced Water: Overview of Composition, Fates and Effects. In: Lee K, Neff J, eds. Produced Water - Environmental Risks and Advances in Mitigation Technologies. New York: Springer Science; 2011. p. 3-54.

37. Tavares SSM, Pardal JM, Mainier FB, da Igreja HR, Barbosa $\mathrm{ES}$, Rodrigues $\mathrm{CR}$, et al. Investigation of the failure in a pipe of produced water from an oil separator due to internal localized corrosion. Engineering Failure Analysis. 2016;61:100-107.

38. Emerson D, Fleming EJ, McBeth JM. Iron-Oxidizing Bacteria: An Environmental and Genomic Perspective. Annual Review Microbiology. 2010;64:561-583.

39. El Hajj H, Abdelouas A, El Mendili Y, Karakurt G, Grambow B, Martin C. Corrosion of carbon steel under sequential aerobic-anaerobic environmental conditions. Corrosion Science. 2013;76:432-440.

40. Gentil V. Corrosão. Rio de Janeiro: LTC; 2011.

41. Pessoa EKR. Água produzida utilizada na reinjeção de poços na recuperação secundária de petróleo - uma discussão sobre os parâmetros de qualidade após o tratamento. [Monograph]. Feira de Santana: Universidade Estadual de Feira de Santana; 2009.

42. Yeung CW, Law BA, Milligan TG, Lee K, Whyte LG, Greer CW. Analysis of bacterial diversity and metals in produced water, seawater and sediments from an offshore oil and gas production platform. Marine Pollution Bulletin. 2011;62(10):2095-2105.

43. Magalhães FCM, Souza HA Jr, Penna MO, Silva ED, Oliveira $\mathrm{HB}$, Andrade CA, et al. Biofouling + sulfate scale in oil production systems - Effects on biocorrosion. International Biodeterioration \& Biodegradation. 1996;37(1-2):126.

44. Videla HA. Biocorrosão, biofouling e biodeterioração de materiais. São Paulo: Edgard Blucher; 2003.

45. Munirasu S, Haija MA, Banat F. Use of membrane technology for oil field and refinery produced water treatment-A review. Process Safety and Environmental Protection. 2016;100:183202.

46. Xu Q, Gao K, Wang Y, Pang X. Characterization of corrosion products formed on different surfaces of steel exposed to simulated groundwater solution. Applied Surface Science. 2015;345:10-17.

47. Shi F, Zhang L, Yang J, Lu M, Ding J, Li H. Polymorphous FeS corrosion products of pipeline steel under highly sour conditions. Corrosion Science. 2016;102:103-113. 